\title{
CYBERLITERATURES: \\ A GLOBAL PERSPECTIVE
}

Guest edited by Dolores Romero López 